\title{
EXECUTIVE REVIEW OF HYDROSTATIC PRESSURE EFFECTS ON SLUDGE PRETREATMENT BY SONICATION
}

\author{
Ngoc Tuan Le ${ }^{1,2,{ }^{*}}$, Carine JULCOUR-LEBIGUE ${ }^{2}$, Henri DELMAS ${ }^{2}$ \\ ${ }^{1}$ University of Science, VNU-HCM City, 227 Nguyen Van Cu, Ward 4, Dist. 5, \\ HoChiMinh City, Vietnam \\ ${ }^{2}$ Université de Toulouse, Laboratoire de Génie Chimique, INP-ENSIACET, \\ 31030 Toulouse, France \\ "Email: Intuan@hcmus.edu.vn,ngoctuan.le@ensiacet.fr
}

Received: 26 December 2014; Accepted for publication: 30 September 2015

\begin{abstract}
Related to ultrasonic (US) pretreatment of sludge, changing the hydrostatic pressure will change the resonance condition of cavitation bubbles and then may drive the system toward resonance conditions, consequently increase the rate and yield of reactions. Nevertheless, nearly all the $U S$ experiments had been carried out at atmospheric pressure. Only a few studies had been focusing on how increasing static pressure affects cavitation. The effect of hydrostatic pressure on sludge disintegration was studied for the first time in the last few years. This work aimed at reviewing the effect of pressure on sludge ultrasonic pretreatment efficiency in different conditions. The major result was that the optimum pressure depends on power input $P_{U S}$, intensity $-I_{U S}$ (or probe size), and temperature $-T$, but not on specific energy input $-E S$, frequency $-F_{S}$, nor sludge type. In general, sludge disintegration efficacy was significantly improved by sonication at the optimum pressure, especially at low ES, leading to a potential of energy input savings in sludge sonication pretreatment, but also in most of ultrasound assisted processes.
\end{abstract}

Keywords: hydrostatic pressure, sludge disintegration, sludge pretreatment, sonication, ultrasonic pretreatment, waste activated sludge

\section{INTRODUCTION}

Despite ultrasonic (US) sludge treatment has reached commercial developments and given rise to many works, and hydrostatic pressure is known as an important parameter, but had hardly been investigated. Thereby, it is necessary be elucidated or confirmed in order to optimize sludge disintegration: Is there an optimum hydrostatic pressure for sludge US pretreatment? If any, how do the other parameters (sludge type, sludge concentration, temperature $-T$, specific energy input $-E S$, power input $-P_{U S}$, intensity $-I_{U S}$, frequency $-F_{S}$ ) affect this optimum and what is the expected gain in terms of energy saving? 
Changing the hydrostatic pressure will change the resonance condition of cavitation bubbles and then may drive the system toward resonance conditions [1], consequently increase the rate and yield of reactions [2 - 4]. More probably, both the cavitation threshold and intensity should increase following an increase in pressure [5], suggesting a possible optimum pressure. Brett and Jellinek [6] stated that bubbles could be visible for gas-applied pressure as high as $16 \mathrm{~atm}$. Nevertheless, nearly all the US experiments have been carried out at atmospheric pressure. Only a few studies have been focusing on how increasing static pressure affects cavitation.

The effect of pressure on sludge ultrasonic pretreatment have been investigated in the last few years. This paper presents an executive review of sludge pretreatment by sonication under pressure, including the relationships between pressure and sludge types, $E S, P_{U S}, I_{U S}, T$, and $F_{S}$ for optimization of sludge US pretreatment efficiency

\section{EFFECT OF PRESSURE ON SONICATION EFFICACY}

Most works on pressure effects concern sonoluminescence and no consensus emerges about an optimum value as reported by Chendke and Fogler [7 - 8]. The early works of Finch [9] indicated the greatest sonoluminescence intensity to be observed in water at about $1.5 \mathrm{~atm}$, but Chendke and Fogler [8] recommended 6 atm in nitrogen-saturated water. In aqueous carbon tetrachloride solutions, the sonoluminescence intensity did not show any monotonous behavior: two peaks at 6 and $12 \mathrm{~atm}$, and almost inhibited above $18 \mathrm{~atm}$ [7]. Increasing superimposed hydrostatic pressures (up to 47.5 bar) resulted in a decrease in volume fraction of cavities [10], then the cavitation damage level in superplastic [11 - 12]. On the other hand, a strong effect of hydrostatic pressure on cavitation was found, e.g. optimum pressure of $4.5 \mathrm{~atm}$ for a maximum aluminum foil erosion rate [13] or 4 bar for 304L stainless steel corrosion rate [14]. Hydrostatic pressure retards both cavity nucleation (reduction of the total number of cavities) and cavity growth (decrease in the sizes of cavities). As a result, larger $U S$ intensity is required to induce bubble oscillations and implosions.

More recent pressure effects again focused attention. Gaitan et al. [15] found the collapse strength to be intensified at elevated pressures in part due to an increased differential pressure between the external liquid and the interior of the bubble. Extended the work of Gaitan et al. [15], Bader et al [16] found the increased acoustic energy stored in the resonant system (i.e. increased peak negative pressure) to be the main reason rather than the increased differential pressure. The overpressure acts to suppress cavitation and increase the amount of stored energy which leads to an increase in the collapse strength and therefore shock wave amplitudes. Besides, the cavitation threshold increases linearly with the static pressure, thus the acoustic pressure amplitude required to reach the cavitation threshold also increases [17]. Yasui et al. [18] showed the optimal static pressure which maximizes the acoustic energy increases as the acoustic amplitude increases or viscosity of liquid decreases, which qualitatively agrees with Sauter et al. [19].

Closer to the present subject, Neppiras and Hughes [20] investigated the influence of pressure (up to $5.8 \mathrm{~atm}$ ) on the disintegration of yeast cells and found an optimum value of 4 atm. As mentioned, the effect of pressure on sludge US pretreatment had hardly been investigated until recent years. The following contents presents its effects in different conditions. The best conditions (combinations) to obtain are expected to enhance sludge disintegration and then to save energy input as sludge pressurization needs only little energy. 


\section{EFFECT OF PRESSURE ON SONICATION PRETREATMENT OF SLUDGE}

\subsection{Effect of hydrostatic pressure on $D D_{C O D}$ for different $E S$ values and sludge types}

Le et al. [21] used mixed sludge to evaluate the effect of pressure on disintegration vs. sonication time. For these tests, 52 experiments were respectively conducted at various $E S$ for different pressure values: 2 bar intervals were used first and then 1 bar intervals at $E S$ of 35000 $\mathrm{kJ} / \mathrm{kg}_{\mathrm{TS}}$. The results are presented in Fig. 1, where $D D_{C O D}$ is plotted as a function of pressure for different $E S$ values.

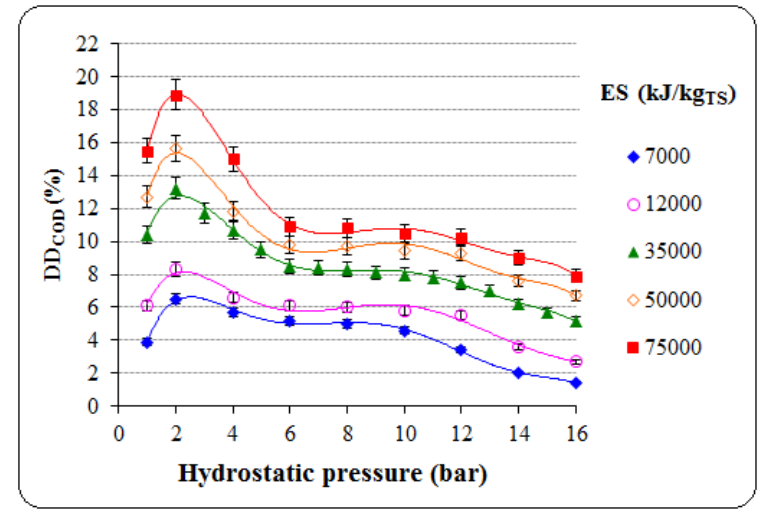

Figure 1. Effect of hydrostatic pressure on mixed sludge disintegration $\left(D D_{C O D}\right)$ for different final $E S$ values: $P_{U S}=150 \mathrm{~W}, 35 \mathrm{~mm}$ diameter probe $(B P), F_{S}=20 \mathrm{kHz}, T S=28 \mathrm{~g} / \mathrm{L}$, and $T=28 \pm 2{ }^{\circ} \mathrm{C}[21]$.

All corresponding curves show the same trends of $D D_{C O D}$ : an initial increase up to 2 bar and a decrease thereafter, noticeably up to 6 bar, before a plateau from 6 to 10 bar approximately and a further decrease. The main result is that for this $U S$ equipment and application, almost the same value of optimum pressure was found regardless of ES. It is also noteworthy that pressure effect appears relatively high at low $E S$, with a maximum improvement of $67 \%$ at $7000 \mathrm{~kJ} / \mathrm{kg}_{\mathrm{TS}}$ and much lower at $75000 \mathrm{~kJ} / \mathrm{kg}_{\text {TS }}$ ( $23 \%$ gain). In addition, the positive effect of pressure up to 2 bar might lead to energy savings in sludge $U S$ pretreatment. For instance, at the optimum pressure, $D D_{C O D}$ obtained with $E S$ of 7000,35000 , and $50000 \mathrm{~kJ} / \mathrm{kg}_{\mathrm{TS}}$ were higher than those at atmospheric pressure with $E S$ of 12000,50000 , and $75000 \mathrm{~kJ} / \mathrm{kg}_{\mathrm{TS}}$, respectively. It is also interesting to note that the decrease of $D D_{C O D}$ beyond the optimal pressure was faster at higher ES..

Additional US experiments on secondary sludge were performed to check for the possible dependence of the pressure effect on sludge type. The results, shown in Fig. 2, indicated that the optimal pressure was again about 2 bar regardless of sludge type also. 


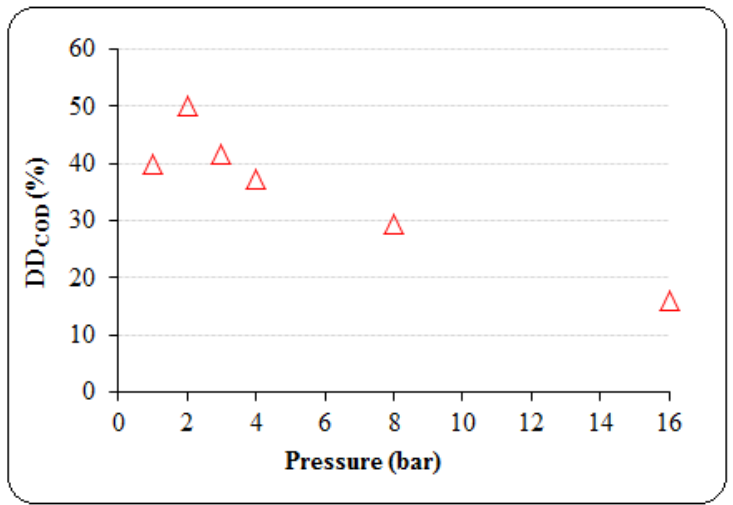

Figure 2. Effect of hydrostatic pressure on secondary sludge disintegration $\left(\mathrm{DD}_{\mathrm{COD}}\right): \mathrm{P}_{\mathrm{US}}=150 \mathrm{~W}, \mathrm{BP}$, $\mathrm{ES}=75000 \mathrm{~kJ} / \mathrm{kg}_{\mathrm{TS}}, \mathrm{F}_{\mathrm{S}}=20 \mathrm{kHz}, \mathrm{TS}=28 \mathrm{~g} / \mathrm{L}$, and $\mathrm{T}=28 \pm 2{ }^{\circ} \mathrm{C}$.

\subsection{Effect of $U S$ power and intensity on the optimal pressure and subsequent $D D_{C O D}$}

This section presents dependences of optimal pressures on $P_{U S}$ and $I_{U S}$ when also varied by changing probe size at same $P_{U S}$, investigated by Delmas et al. [22]. Sonication $(20 \mathrm{kHz})$ was applied on secondary sludge at the same $E S$ of $50000 \mathrm{~kJ} / \mathrm{kg}_{\mathrm{TS}}$ varying hydrostatic pressure between 1 and 6 bar (with 0.5 bar intervals). Results are presented in Fig. 3.

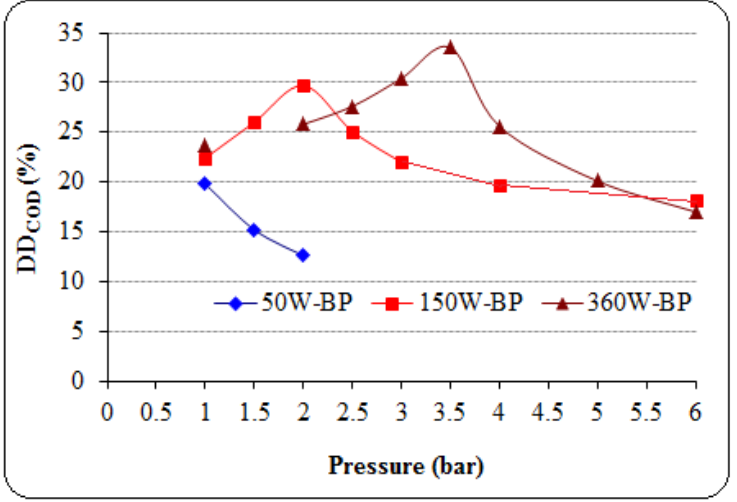

(a)

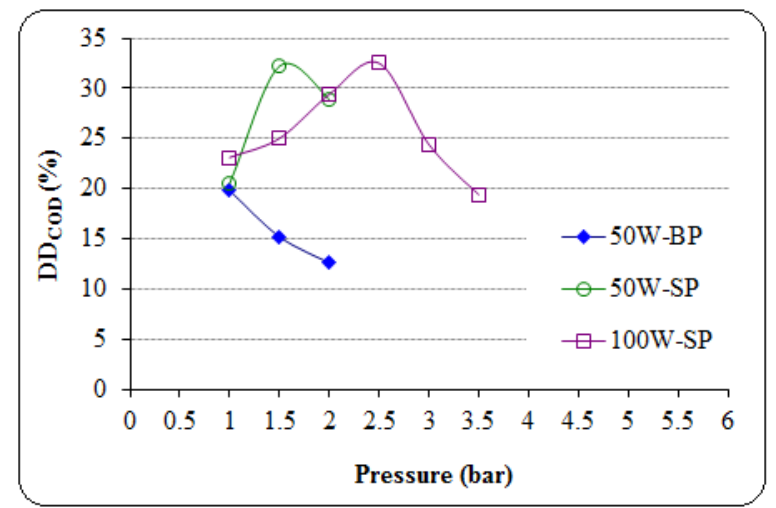

(b)

Figure 3. Effect of hydrostatic pressure on $\mathrm{DD}_{\mathrm{COD}}$ of secondary sludge for different $\mathrm{P}_{\mathrm{Us}}$ and probe sizes $\left(\mathrm{F}_{\mathrm{S}}=20 \mathrm{kHz}, \mathrm{ES}=50000 \mathrm{~kJ} / \mathrm{kg}_{\mathrm{TS}}, \mathrm{T}=28^{\circ} \mathrm{C}\right.$, and $\left.\mathrm{TS}=28 \mathrm{~g} / \mathrm{L}\right):$ (a) $\mathrm{BP}$, (b) $13 \mathrm{~mm}$ diameter probe (SP) and $\mathrm{BP}$ at same $\mathrm{P}_{\mathrm{US}}[22]$.

Figure 3 indicates that the optimum pressure is a function of both $P_{U S}$ and probe size. First with the same probe $(B P)$, the optimum shifts toward higher pressure when increasing $P_{U S}$ (and thus $I_{U S}$ proportionally): 1 bar (or even lower) at $50 \mathrm{~W}, 2$ bar at $150 \mathrm{~W}$, and 3.5 bar at $360 \mathrm{~W}$ (Fig. 3a). At the much higher intensity delivered by $S P$, the optimum pressure was found at 1.5 bar at $50 \mathrm{~W}$ and 2.5 bar at $100 \mathrm{~W}$ (Fig. 3b). The decrease in $D D_{C O D}$ observed when raising pressure above atmosphere with $B P$ at $50 \mathrm{~W}$ clearly shows the expected positive effect of pressure only occurs at sufficient $I_{U S}$ (or acoustic pressure), unless cavitation intensity decreases. In other words, at same $P_{U S}(50 \mathrm{~W})$, different effects of pressure resulting from different emitter 
surfaces indicate the dependence of optimum pressure on $I_{U S}$. Sonication under convenient excess pressure significantly improves sludge disintegration compared to atmospheric sonication, especially at high $I_{U S}$ and at low $E S$ as previously found in Fig 1: up to $95 \%$ and $56 \%$ of $D D_{C O D}$ improvements for $S P$ and $B P$, respectively (Fig. 4). Interestingly, at optimum pressures, better sludge disintegration was found at $50 \mathrm{~W}(S P)$ than at $150 \mathrm{~W}(B P)$.

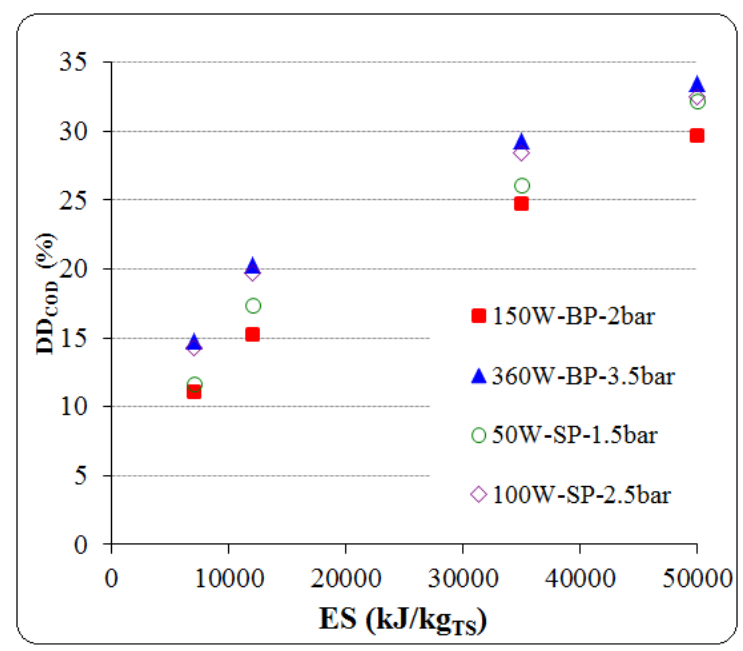

Figure 4. Disintegration degree of secondary sludge as a function of ES at the optimal pressures of each configuration $\left(\mathrm{P}_{\mathrm{US}}\right.$, probe size $): \mathrm{F}_{\mathrm{S}}=20 \mathrm{kHz}, \mathrm{TS}=28 \mathrm{~g} / \mathrm{L}$, and $\mathrm{T}=28 \pm 2{ }^{\circ} \mathrm{C}$.

Figure 5 depicts the effect of $I_{U S}$ under different pressures at same $P_{U S}(50 \mathrm{~W})$ on secondary sludge disintegration. First, the role of $I_{U S}$ (at same $P_{U S}$ of $50 \mathrm{~W}$ with different probe sizes, corresponding to $I_{U S}$ of 5.2 and $37.7 \mathrm{~W} / \mathrm{cm}^{2}$ ) is insignificant at atmospheric pressure. However, its effect around the optimal pressure becomes extremely high, e.g. at $50000 \mathrm{~kJ} / \mathrm{kg}_{\mathrm{TS}}, D D_{C O D}$ obtained with $S P$ is 2.1 and 2.3-fold higher than with $B P$ at 1.5 and 2 bar, respectively. Such effect, much higher than that of $P_{U S}$ at atmospheric pressure, highlights the complex interplay of the various parameters on cavitation efficiency.

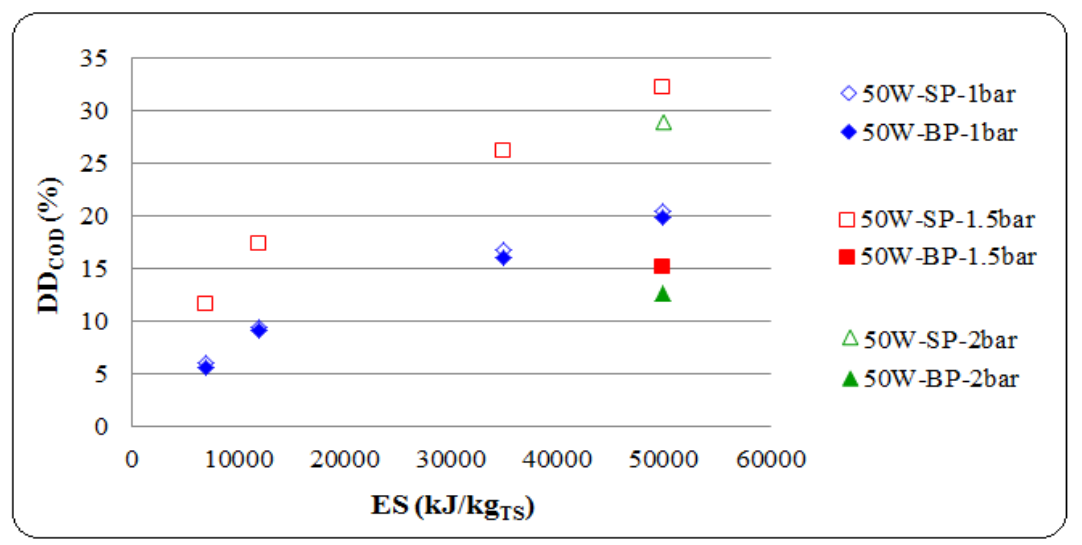

Figure 5. Effect of ES, US intensity (at same $\mathrm{P}_{\mathrm{US}}$ ) and pressure on secondary sludge disintegration: $\mathrm{F}_{\mathrm{S}}=20 \mathrm{kHz}, \mathrm{TS}=28 \mathrm{~g} / \mathrm{L}$, and $\mathrm{T}=28 \pm 2{ }^{\circ} \mathrm{C}$. 
According to Lorimer and Mason [5], increasing hydrostatic pressure leads to an increase in both the cavitation threshold and the intensity of cavity collapse, which can be explained as follows: when an acoustic field is applied to a liquid, the sonic vibrations create an acoustic pressure $\left(P_{a}\right)$ which must be considered to be additional to the ambient hydrostatic pressure $\left(P_{h}\right)$ already present in the medium. Theoretical calculations from Noltingk and Neppiras [23], Flynn [24], and Neppiras [25], assuming an adiabatic collapse of the bubbles, allow estimating the temperature $\left(T_{\max }\right)$ and pressures $\left(P_{\max }\right)$ within the bubble at the moment of total collapse according to:

$$
T_{\max }=T_{o}\left\{\frac{P_{m}(\gamma-1)}{P}\right\} \quad P_{\max }=P\left\{\frac{P_{m}(\gamma-1)}{P}\right\}^{\left(\frac{\gamma}{\gamma-1}\right)}
$$

where $T_{o}$ is temperature of the bulk solution, $\gamma$ is the ratio of specific heats of the gas (or gas vapour) mixture, $P$ is the pressure in the bubble at its maximum size and usually assumed to be the vapour pressure of the liquid, $P_{m}$ is the total solution pressure at the moment of transient collapse $\left(P_{m} \sim P_{h}+P_{a}\right)$.

Thereby, increasing $P_{h}$ leads to an increase in $P_{m}$, thus $P_{\max }$ and $T_{\max }$, i.e. cavitation intensity. On the other hand, as abovementioned, increasing $P_{h}$ also results in an increase in cavitation threshold, thus the amplitude of acoustic pressure $\left(P_{A}\right.$ directly depending on $\left.I_{U S}\right)$ should be in excess as compared to hydrostatic pressure for cavitation bubbles to be generated: indeed it can be qualitatively assumed that if $P_{h}-P_{A}>0$, there is no resultant negative pressure and cavitation cannot occur.

All these combined effects explain why different $I_{U S}$ values resulting either from a change of $P_{U S}$ or probe size lead to different optimal pressures (Fig. 3) and why $I_{U S}$ effect at given $P_{U S}$ becomes important when moderately raising the pressure, resulting in an inhibition of cavitation for the big probe and increased cavitation efficiency for the small one (Fig. 5).

In short, an optimum of pressure is achieved due to opposite effects of hydrostatic pressure: a reduction of the number of cavitation bubbles due to a higher cavitation threshold, but a more violent bubble collapse. This optimum pressure is both US power and intensity dependent.

\subsection{Optimal pressure under adiabatic sonication}

Based on isothermal results, Le et al. [26] searched optimal values of hydrostatic pressure under adiabatic $U S$ in the $1-5$ bar range at a given $E S$ value, but for different $P_{U S}(100-360 \mathrm{~W})$ and probe sizes. Results are shown in Fig. 6 where same $E S\left(50000 \mathrm{~kg} / \mathrm{kg}_{\mathrm{TS}}\right)$ but different treatment durations were applied. This should however not much change the location of the optimum pressure, only the final corresponding $D D_{C O D}$ value (for instance increased from $60 \%$ to $66 \%$ at $360 \mathrm{~W}$ when after $33 \mathrm{~min}$ of $U S$, the solution was let on stirring up to $78 \mathrm{~min}$, to match the duration of the $150 \mathrm{~W}$ experiment). Note also that data of Fig. 6 do not correspond to the same final temperature. 


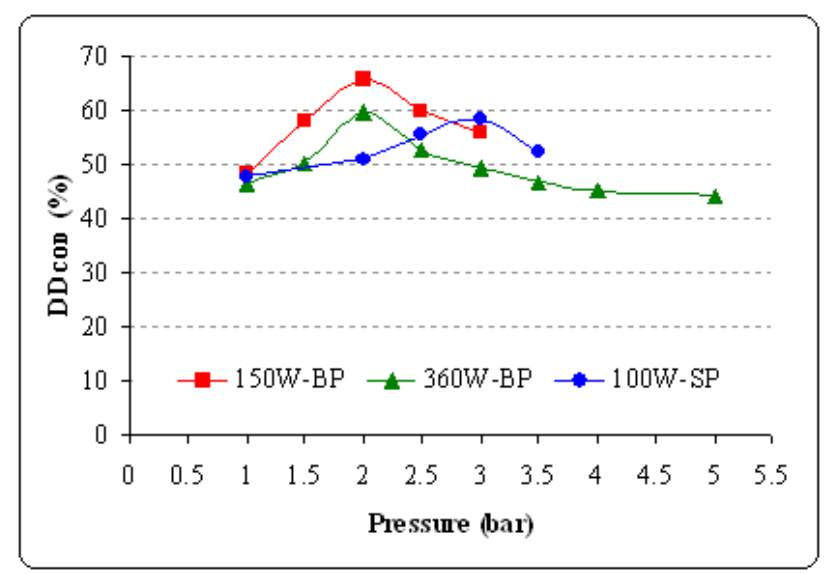

Figure 6. Effect of pressure on $\mathrm{DD}_{\mathrm{COD}}$ under adiabatic sonication for different combinations of $\mathrm{P}_{\mathrm{Us}}$-probe sizes: $\mathrm{ES}=50000 \mathrm{~kJ} / \mathrm{kgTS}, \mathrm{F}_{\mathrm{S}}=20 \mathrm{kHz}$, secondary sludge with TS $=28 \mathrm{~g} / \mathrm{L}$ [26].

Surprisingly, in adiabatic conditions, the same optimum pressure of 2 bar was obtained with the same probe $(B P)$ at different $P_{U S}(150$ and $360 \mathrm{~W})$ while an increase would be expected at higher power according to isothermal data (section 3.2). The respective evolution of optimal pressure vs. $P_{U S}$ is complex in adiabatic condition and somewhat different with respect to isothermal case as the result of opposite effects of $T$ on cavitation intensity and thermal hydrolysis. As observed, optimum pressures found under isothermal US were shifted differently depending on $T$ profiles: slight increase at the moderate $T$ resulting from $100 \mathrm{~W}$ adiabatic $U S$ with $S P$ (from 2.5 bar -Fig. 3b- to 3 bar -Fig. 6), but a decrease at extreme $T$ found at $360 \mathrm{~W}$ with $B P$ (from 3.5 bar -Fig. 4a- to 2 bar-Fig. 6). This result was not expected and would deserve more analysis based on single cavitation bubble dynamics at high pressure and high $T$.

\subsection{Dependence of hydrostatic pressure effect on sound frequency}

The same $E S$ of $35000 \mathrm{~kJ} / \mathrm{kg}_{\mathrm{TS}}$ was applied using the $12 \mathrm{kHz}$ sonicator with $P_{U S}$ of 150 and $360 \mathrm{~W}$ through the big probe under pressure. Based on results at $20 \mathrm{kHz}$, the pressure range 1-4 bar was more carefully investigated with closer intervals of pressure: 0.25 bar. Results are presented in Fig. 7 [22].

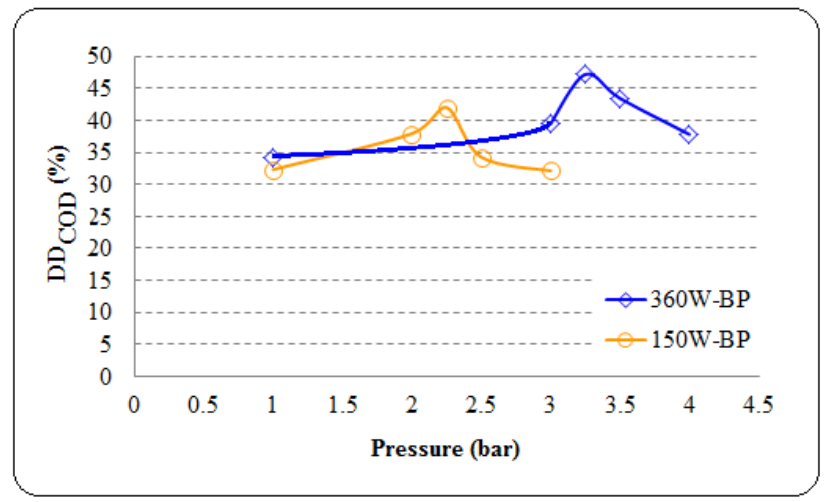

Figure 7. Effect of hydrostatic pressure on $D D_{C O D}$ of secondary sludge for different $P_{U S}: B P, E S=35000$ $\mathrm{kJ} / \mathrm{kg}_{\mathrm{TS}}, F_{S}=12 \mathrm{kHz}, T S=28 \mathrm{~g} / \mathrm{L}$, and $T=28^{\circ} \pm 2 \mathrm{C}[22]$. 
As previously found at $20 \mathrm{kHz}$ (see $\S 3.2$ ), the optimum pressure shifts when increasing $I_{U S}$. Besides, the location of this optimum seems to be independent from sound frequency in the restricted investigated range: 2 bar at $150 \mathrm{~W}$ and 3.5 bar at $360 \mathrm{~W}$ (using 0.5 bar intervals) for 20 $\mathrm{kHz}$ as compared to 2.25 bar at $150 \mathrm{~W}$ and 3.25 bar at $360 \mathrm{~W}(0.25$ bar intervals) for $12 \mathrm{kHz}$ sonicator.

\section{CONCLUSIONS}

The effect of hydrostatic pressure on sludge sonication disintegration was studied in recent years and reviewed in this work. As far as sufficient acoustic intensity was provided, an optimum pressure (>1 bar) was found due to an increase in both cavitation threshold and cavitation intensity when increasing pressure. While the effect of $I_{U S}$ on $D D_{C O D}$ was minor at atmospheric pressure, it was found to be much higher under convenient pressure. The most effective isothermal $U S$ would be high $P_{U S}$, low $F_{S}$, convenient pressure, and adequate TS. Besides, positive effect of pressure associated with high $P_{U S}$ adiabatic $U S$ was also found. Interestingly, the optimum pressure could be affected by $T$. Concerning disintegration, a slight increase was obtained at moderate $T$, mainly due to higher numbers of cavitation bubbles, then a decrease at extreme $T$ due to the less violent collapse of cavitation bubbles containing too much vapor. The major result was that the location of the optimal pressure depends on $P_{U S,} I_{U S}$ (or probe size), and $T$, but not on $E S, F_{S}$, nor sludge type. Such an important result would have to be checked in other $U S$ applications. In general, sludge disintegration efficacy was significantly improved by sonication at the optimum pressure as compared to that at atmospheric pressure, especially at low $E S$, leading to a potential of energy input savings in sludge sonication pretreatment, but also in most of ultrasound assisted processes (since the energy to pressurize the solution to the corresponding moderate pressure levels is much lower than the observed energy savings).

\section{REFERENCES}

1. Thompson L. H. and Doraiswamy L. K., REVIEWS - Sonochemistry: Science and Engineering, Ind. Eng. Chem. Res. 38 (1999) 1215-1249.

2. Cum G., Gallo R., Spadaro A. - Effect of Static Pressure on the Ultrasonic Activation of Chemical Reactions. Selective Oxidation at Benzylic Carbon in the Liquid Phase. J. Chem. Soc. Perkin Trans. 2 (1988) 375-383.

3. Cum G., R. Gallo, Spadaro A. - Temperature Effects in Ultrasonically Activated Chemical Reactions, IL Nuovo Cimento. 12 D (10) 1990.

4. Cum G., Galli G., Gallo R., Spadaro A. - Role of frequency in the ultrasonic activation of chemical reactions, Ultrasonics. 30 (4) (1992) 267-270.

5. Lorimer J. P. and Mason T. J. - Sonochemistry: Part 1-The Physical Aspects, Chem. Soc. Rev., 16 (1987) 239-274.

6. Brett H. W. W. and Jellinek H. H. G. - Degradation of long-chain molecules by ultrasonic waves. Part VI. Effect of pressure. J. Polym. Sci. 21 (1956) 535-545.

7. Chendke P. K. and Fogler H. S. - Sonoluminescence and Sonochemical Reactions of Aqueous Carbon Tetrachloride Solutions, J. Phys. Chem. 87 (1983a) 1362-1369. 
8. Chendke P. K. and Fogler H. S. - Effect of Static Pressure on the Intensity and Spectral Distribution of the Sonoluminescence of Water, J. Phys. Chem. 87 (1983b) 1644-1648.

9. Finch R.D. The dependence of sonoluminescence on static pressure. Brit J Appl Phys. 16 (1965) 1543-1553.

10. Pilling J. and Ridley N. - Effect of hydrostatic pressure on cavitation in superplastic aluminum-alloys, Acta Metallurgica 34 (4) (1986) 669-679.

11. Chokshi A. H., Mukherjee A. K., Duba A. G., Durham W. B., Handin J. W. and Wang H. F. (Eds.) - The Brittle-Ductile Transition in Rocks, Geophysical Monograph, The American Geophysical Union, Washington, DC 56 (1990) p. 83.

12. Chokshi A. H. and Mukherjee A. K. - The influence of hydrostatic pressure on grain boundary sliding in superplasticity: implications for cavitation, Materials Science and Engineering A-Structural Materials Properties Microstructure and Processing 171 (1-2) (1993) 47-54.

13. Dezhkunov N., Lernetti G., Francescutto A., Reali M., Ciuti P. - Cavitation Erosion and Sonoluminescence at High Hydrostatic Pressures, ACUSTICA 83 (1) (1997) 19-24.

14. Whillock G.O.H., Harvey B.F. - Ultrasonically enhanced corrosion of 304L stainless steel II: The effect of frequency, acoustic power and horn to specimen distance, Ultrasonics Sonochemistry 4 (1997b) 33-38.

15. Gaitan D. F., Tessien R. A., Hiller R. A., Gutierrez J., Scott C., Tardif H., Callahan B., Matula T. J., Crum L. A., Holt R. G., Church C.C., Raymond J. L. - Transient cavitation in high-quality-factor resonators at high static pressures, Journal of the Acoustical Society of America. 127 (6) (2010) 3456-3465.

16. Bader K. B., Mobley J., Church C. C. - The effect of static pressure on the strength of inertial cavitation events, Journal of the Acoustical Society of America 132 (4) (2012b) 2286-2291.

17. Bader K. B., Raymond J. L., Mobley J., Church C.C. - The effect of static pressure on the inertial cavitation threshold, J. Acoust. Soc. Am. 132 (2) (2012a) 728-737.

18. Yasui K., Towata A., Tuziuti T., Kozuka T., Kato K. - Effect of static pressure on acoustic energy radiated by cavitation bubbles in viscous liquids under ultrasound, Journal of the Acoustical Society of America 130 (5) Special Issue (2011) 3233-3242.

19. Sauter M., Emin A., Schuchmann H. P., Tavman S. Influence of hydrostatic pressure and sound amplitude on the ultrasound induced dispersion and de-agglomeration of nanoparticles, Ultrason. Sonochem. 15 (2008) 517-523.

20. Neppiras E. A. and Hughes D. E. - Some Experiments on the Disintegration of Yeast by High Intensity Ultrasound, Biotechnology And Bioengineering 6 (1964) 247-270.

21. Le N.T., Julcour-Lebigue C., Delmas H. - Ultrasonic sludge pretreatment under pressure. Ultrason. Sonochem. 20 (2013) 1203-1210.

22. Delmas H., Le N.T., Barthe L., Julcour-Lebigue C. - Optimization of hydrostatic pressure at varied sonication conditions e power density, intensity, very low frequency e for isothermal ultrasonic sludge treatment, Ultrason. Sonochem. 25 (2015) 51-59.

23. Noltingk B. E., Neppiras E. A. - Cavitation Produced by Ultrasound. Proc. Phys. Soc., London 63B (1950) 674-685. 
24. Flynn H. G. - Physics of acoustic cavitation in liquids. In: Physical Acoustics, Vol. 1 (Mason WP ed.). Academic Press, New York, 1964, Part B, pp. 57-172.

25. Neppiras E. A. - Acoustic cavitation. Phys. Rep. 61 (1980) 160-251.

26. Le N.T., Julcour-Lebigue C., Barthe L., Delmas H. - Optimisation of sludge pretreatment by low frequency sonication under pressure, Journal of Environmental Management 165 (2016) 206-212.

\title{
TÓM TẮT
}

\section{TỔNG QUAN ẢNH HƯỞNG CỦA ÁP SUÂT THỦY TĨNH LÊN HIỆU QUẢ TIỀN XỦ LÍ BÙN THẢI BẰNG CÔNG NGHỆ SIÊU ÂM}

\author{
Lê Ngọc Tuấn ${ }^{1,2, *}$, Carine JULCOUR-LEBIGUE², Henri DELMAS ${ }^{2}$ \\ Đại học Khoa học Tụ nhiên, Đại học Quốc gia TpHCM, \\ 227 Nguyễn Văn Cù, P.4, Quận 5, TpHCM \\ ${ }^{2}$ Université de Toulouse, Laboratoire de Génie Chimique, INP-ENSIACET, \\ 31030 Toulouse, France
}

Email: $\underline{\text { lntuan @ hcmus.edu.vn }}$

Liên quan đến tiền xử lí bùn thải bằng công nghệ siêu âm, thay đổi áp suất thủy tĩnh sẽ thay đổi điều kiện cộng hưởng của bong bóng cavitation và có thể dẫn đến điều kiện cộng hưởng của hệ thống, theo đó là sự gia tăng tốc độ và năng suất của phản ứng. Tuy nhiên, hầu như tất cả các thí nghiệm siêu âm đều được thực hiện ở áp suất không khí. Ảnh hưởng của áp suất thủy tĩnh đến việc phân rã bùn thải mới được nghiên cứu trong những năm gần đây. Nghiên cứu này nhằm mục tiêu tổng quan ảnh hưởng của áp suất đến hiệu quả tiền xử lí bùn thải bằng công nghệ siêu âm ở các điều kiện khác nhau. Kết quả quan trọng của nghiên cứu là sự phụ thuộc của áp suất tối ưu vào $P_{U S}, I_{U S}$ (hay kích thước đầu dò siêu âm) và nhiệt độ; không phụ thuộc $E S, F_{S}$ cũng như loại bùn thải. Một cách tổng quát, hiệu quả phân rã bùn thải được cải thiện đáng kể khi siêu âm trong điều kiện áp suất tối ưu, đặc biệt ở $E S$ thấp, mở ra tiềm năng to lớn trong việc tiết kiệm năng lượng không chỉ đối với công nghệ tiền xử lí bùn thải mà còn với hầu hết các quá trình ứng dụng siêu âm nói chung.

Từ khóa: áp suất thủy tĩnh, phân rã bùn thải, tiền xử lí bùn thải, siêu âm, tiền xử lí bằng siêu âm, bùn thải hoạt tính. 